\title{
Identification and Quantification of Heavy Metals Concentrations in Pistacia
}

\author{
Gholamhossein DAVARYNEJAD ${ }^{1 *}$,Mehdi ZAREI', Peter Tamas NAGY ${ }^{2}$ \\ ${ }^{1}$ Department of Horticultural Science, Faculty of Agriculture, Ferdowsi University of Mashhad, \\ P.O., Mashhad,Iran; davarynej@um.ac.ir ( ${ }^{*}$ corresponding author) \\ ${ }^{2}$ Institute of Environmental Sciences, Faculty of Natural Resources Management and Rural Development, \\ Károly Róbert College, Gyöngyös, Hungary
}

\begin{abstract}
The levels of heavy metals are very important in pistachio nuts, because the edible nuts have an important and increasing role in human nutrition. Pistachio is one of the native nuts of Iran which contains high genetic resources, but there is insufficient information regarding nutritional properties and other elements like heavy metals. The objective of the present study was to investigate and compare heavy metals contents in the kernels of various pistachio samples including: 'Daneshmandi', 'Sephid,' 'Garmeh', 'Momtaz', 'Ahmad Aghaei,' 'Badami Zarand', Pistacia atlantica Desf. ('Baneh'), Pistacia vera 'Sarakhs' and chance seedling as 'Non-grafted 1', 'Non-grafted 2' and 'Non-grafted 3'. Inductively coupled plasma emission spectrophotometer (ICP) was used for the determination of aluminium, chromium, nickel, copper, strontium, arsenic, cadmium and cobalt concentrations in pistachio kernels. This study showed that there were significant differences among the samples in all measured heavy metals except the arsenic, cadmium and cobalt. The content of

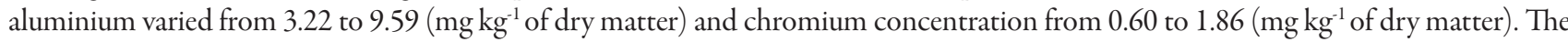
nickel content of examined pistachio samples was found between 0.43 and $3.63\left(\mathrm{mg} \mathrm{kg}^{-1}\right.$ of dry matter) and copper ranged from 3.20

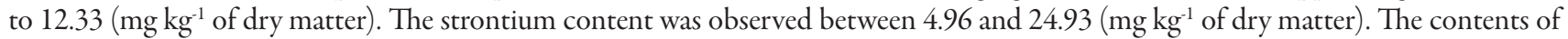
arsenic, cadmium and cobalt not reported, because their amounts were lower than the detection limit of the applied measuring method (ICP). These data demonstrated that the concentrations of heavy metals in pistachios varied by cultivar.
\end{abstract}

Keywords: chemical analysis, cultivar, human diet, pistachio, trace elements

\section{Introduction}

Heavy metals have positive and negative effects on the human health. According to Munoz-Olivas et al. (2001), Jalbani et al. (2007) heavy metals can be classified as potentially toxic (aluminium, arsenic, cadmium, etc.,) and essential (copper, iron, zinc, etc.). Humans are exposed to heavy metals in many different ways such as; by ingestion of contaminated water and food, and by inhalation of air pollutants or contaminated soil particles (Bordajandi et al., 2004). Long-term exposures to toxic elements can be very harmful even at low concentration but the intake of too much of essential metals can also cause produce toxic effects (Celik and Oehlenschlager, 2007).

In the near past years, the increasing demand of food safety has stimulated research regarding the risk associated with consumption of contaminated foodstuffs by pesticides and heavy metals or toxins (D'Mello, 2003). There have been studies on heavy metals in mango and almond (Ademoroti, 1986), strawberry (Ward and Savage, 1994), plantain (Selema and Farago, 1996), quince and grape (Pinochet et al., 1999), lemon, sweet orange and grape fruits (Gorinstein et al., 2001), orange (Rossini et al., 2003), chi$\mathrm{ku}$, papaya, mango, muskmelon and apple (Parveen et al., 2003), banana, pineapple and papaya (Santos et al., 2004), date palm (Williams et al., 2005) and apricot (Davarynejad et al., 2010; Saracoglu et al., 2009).

Pistachio (Pistachia vera L.) belongs to the Anacardiaceae family, and is one of the important tree nuts. It has been cultivated widely in Iran, Turkey, Syria, Greece, Italy and United States, and its cultivation has increased in recent years (Kucukoner and Yurt, 2003). Iran is one of the most important pistachio producers and exporters in the world, and its total production in 2008 was 635,577 tons (FAO, 2008). The popularity of pistachio is mainly due to their nutritional components including; fatty acids, minerals, vitamins, sterols, phenolic compounds and antioxidant properties (Tsantili et al., 2010). It is widely consumed as a snack food, both raw and roasted, confectionery ingredient in cakes, ice cream, bread and sauces.

In spite of various pistachio cultivars grown in different regions of the Iran, the heavy metals of Iranian pistachio cultivars have not been evaluated in detail. Such data will assist in the cultivar selection for safety food production to meet market demand and the conception of healthy diet. Therefore, the aim of the present study was to analyze and compare the heavy metals concentrations in the kernels of various pistachio samples grown in Iran. In addition, differences between pistachio of commercial, non-grafted and wild groups were compared. 


\section{Materials and methods}

\section{Pistachio samples}

Pistachio samples were studied: 'Daneshmandi,' 'Sephid,' 'Garmeh', 'Momtaz,' 'Ahmad Aghaei,' 'Badami Zarand' (Commercial group), Pistacia atlantica Desf. ('Baneh'), Pistacia vera 'Sarakhs' (Wild group) and chance seedling as 'Non-grafted 1', Non-grafted 2' and 'Non-grafted 3' (Nongrafted group). The samples at commercial maturity stage were hand harvested in 2009. Mature trees (18 year-old) randomly selected to represent the population of the plantation from Feyzabad of the Khorasan-e-Razavi province, Iran. Feyzabad is located on the north east part of Iran at $35^{\circ} 01^{\prime} \mathrm{N}$ latitude and $58^{\circ} 78^{\prime} \mathrm{E}$ longitude. The average temperature, the amount of rainfall and relative humidity in growing season of 2009 were $28.65^{\circ} \mathrm{C}, 20 \mathrm{~mm}$ and $26 \%$, respectively. Soil is a sand-loam, EC $=4.12\left(\mathrm{ds} \mathrm{m}^{-1}\right)$ and soil $\mathrm{pH}=7.21$. The trees were spaced 6 and $3 \mathrm{~m}$ between and along the rows, respectively. Trees were irrigated every 24 days and fertilized with $50 \mathrm{~kg} \mathrm{~h}^{-1}$ of nitrate ammonium. All samples were grown under the same geographical conditions and with the same applied agronomic practices. The air dried pistachio nuts were used for chemical analysis in four of replications.

\section{Chemical analysis of heavy metals}

Samples were prepared in accordance with Hungarian standard (MSZ-08-1783-15, 1985). Kernels were digested with concentrate $\mathrm{HNO} 3-\mathrm{H} 2 \mathrm{O} 2$ digester mixture: $5 \mathrm{~g}$ fresh kernel was digested at $120^{\circ} \mathrm{C}$ during three hours in a Teflon digestor. Digested samples were diluted with distilled water to $100 \mathrm{~cm} 3$. Examined elements were measured by Thermo Jarrell Ash Poly-scan 61E and Thermo Electron Corporation IRIS Intrepid II XDL Inductively coupled plasma emission spectrophotometers (ICP) (Davarynejad et al., 2010).

\section{Statistical analysis}

This experiment was conducted according to completely randomized design with 4 replications (each replicate contained 5 individual kernels). Data were analyzed by Statistical Analysis System (SAS) software version 9.1 using analysis of variance (ANOVA) and differences among means were determined for significance at $\mathrm{P}<0.05$ using Tukey's test.

\section{Results and discussion}

\section{Aluminium}

A great variation in terms of aluminium content was observed among the pistachio samples (3.22-9.59 $\mathrm{mg} \mathrm{kg}^{-1}$ of dry matter) and the differences were statistically significant (Fig. 1). The highest amount of aluminium was ob- served in 'Baneh', followed by 'Non-grafted 1' and 'Sephid', while the lowest was in 'Garmeh'. Also, the mean values of aluminium were significantly different among the three groups of pistachio. The aluminium content of the wild, non-grafted and commercial groups comprised 7.77, 6.70 and $5.36 \mathrm{mg} \mathrm{kg}^{-1}$ of dry matter, respectively (Fig. 2).

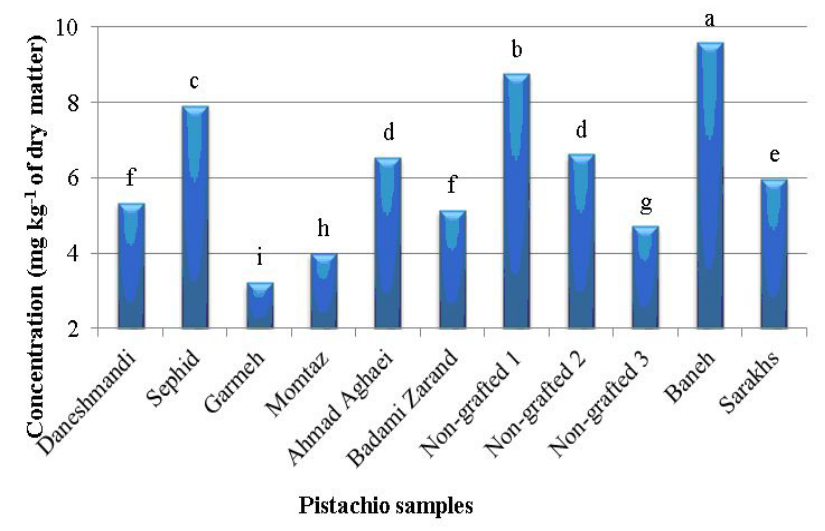

Fig. 1. The aluminium concentration of eleven Iranian pistachio samples. (Each column with different letters is significantly different $(\mathrm{P}<0.05)$

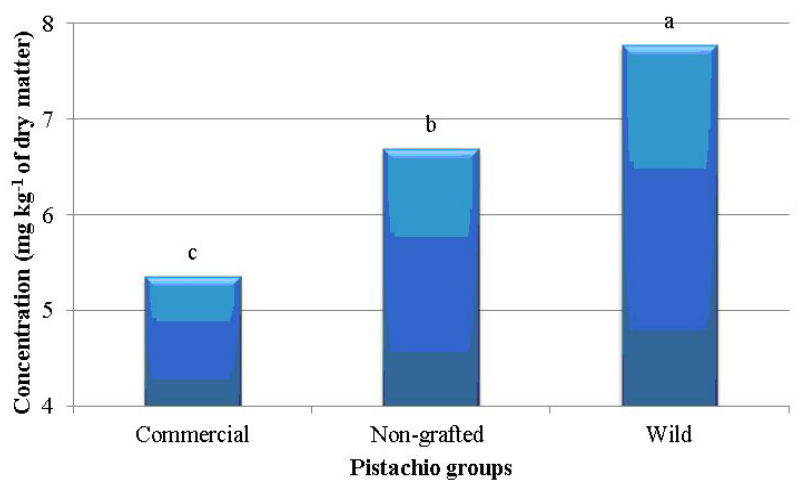

Fig. 2. The aluminium concentration of three Iranian pistachio groups. (Each column with different letters is significantly different $(\mathrm{P}<0.05)$

The aluminium concentration of pistachio samples have not been studied in detail yet. Saracoglu et al. (2009) reported that the aluminium concentration in dried apricot samples of Turkey ranged from 0.08 to $0.22 \mathrm{mg} \mathrm{kg}^{-1}$ of dry matter. The content of aluminium in plants is depended on several factors, like plant species (Biego et al., 1998).

Aluminium $(\mathrm{Al})$ is an abundant element in earth's crust, but it's not considered to be an essential element in humans. The uptake of aluminium can take place through food, breathing and by skin contact. Long lasting uptakes of significant concentrations of aluminium can lead to serious health effects such as; damage to the central nervous system, dementia, memory loss, listlessness, severe trem- 
440

bling and kidney patients (Narin et al., 2004; Shokrollahi et al., 2008). Based on WHO statistics (WHO, 1989), the permissible aluminium dose for an adult is quite high (60 $\mathrm{mg}$ day $\left.^{-1}\right)$. The average content of aluminium of pistachio samples was $6.16 \mathrm{mg} \mathrm{kg}^{-1}$ of dry matter. In this study, we found low concentrations of aluminium in studied pistachio samples, which may not be harmful to human health. It means that an adult can eat approximately $10 \mathrm{~kg}$ pistachio a day to reach this threshold (not calculating other sources).

\section{Chromium}

Significant variation in chromium concentration was found among the eleven samples of pistachio and the values ranged from 0.60 to 1.86 ( $\mathrm{mg} \mathrm{kg}^{-1}$ of dry matter). The highest level of chromium was observed for 'Daneshmandi', followed by 'Garmeh', while the lowest was in 'Non-grafted 3' (Fig. 3). The results also showed that the chromium content was not significantly different between groups of commercial and wild, while significantly differences were observed between groups of non-grafted and commercial or groups of non-grafted and wild. The samples of commercial had the highest chromium content (1.14 $\mathrm{mg} \mathrm{kg}^{-1}$ of dry matter) while the non-grafted samples had the lowest chromium content $\left(0.78 \mathrm{mg} \mathrm{kg}^{-1}\right.$ of dry matter) (Fig. 4).

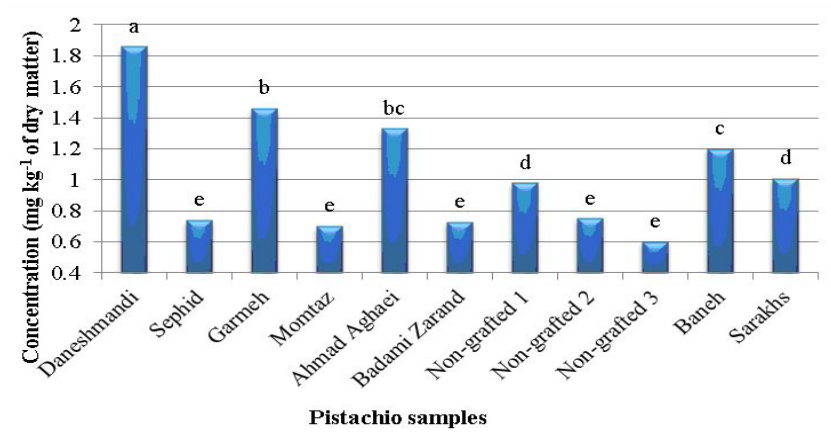

Fig. 3. The chromium concentration of eleven Iranian pistachio samples. (Each column with different letters is significantly different $(\mathrm{P}<0.05)$

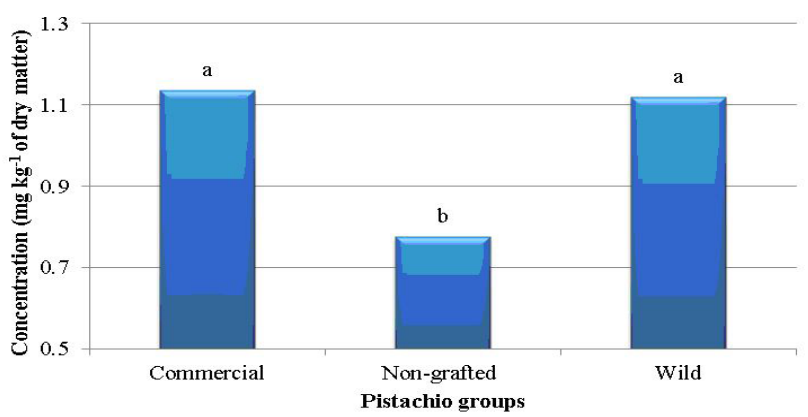

Fig. 4. The chromium concentration of three Iranian pistachio groups. (Each column with different letters is significantly different $(P<0.05)$
The chromium level of pistachio samples have not been investigated in detail yet. The chromium content was found in the range of 3.23-6.43 mg kg-1 in apricots of Pakistan by Zahoor and Zahoor (2003) and in the range of $0.32-0.64 \mathrm{mg} \mathrm{kg}^{-1}$ in the apricots of Turkey by Saracoglu et al. (2009). Although, there are very low concentrations of chromium ( $\mathrm{Cr}$ ) in the human body, it is a beneficial element and essential for human growth and development. It is important role in glucose, lipid and protein metabolism (Cobo et al., 1995; Jirapinyo et al., 1985; Offenbacher and Pi-Sunyer, 1988). For most people eating food that contains chromium is the main route of chromium uptake as chromium occurs naturally in many vegetables, fruits, meats, yeasts and grains. Nowadays, the exhaustion of chromium is a real danger, because of the abundant consumption of high sugar foods that increase the exhaustion of it. Of course the intake of too much of chromium can also cause harmful health effects for instance hepatitis, gastritis, ulcers and lung cancer (Parveen et al., 2003).

According to Saracoglu et al. (2009) a range of chromium intake between 50 and $200 \mu \mathrm{g} \mathrm{day}{ }^{-1}$ is recommended for adults. Our results indicated that the mean content of chromium in pistachio samples was $1.03 \mathrm{mg} \mathrm{kg}^{-1}$ of dry matter. It means that pistachio is an excellent source of chromium. Eating $200 \mathrm{~g}$ pistachio per day covers the daily intake of an adult.

\section{Nickel}

In this study, the differences in nickel content among the pistachio samples were significant ranging from 0.43 to $3.63 \mathrm{mg} \mathrm{kg}^{-1}$ of dry matter. The highest concentration of nickel was observed for 'Garmeh', followed by 'Sephid', 'Non-grafted 1', 'Daneshmandi' and 'Momtaz' while the lowest was in 'Ahmad Aghaei' (Fig. 5). There was a significant difference between the commercial group and the other groups (wild and non-grafted).

The mean nickel contents of the commercial, nongrafted and wild groups were 1.50, 0.96 and $0.94 \mathrm{mg} \mathrm{kg}^{-1}$ of dry matter, respectively (Fig. 6).

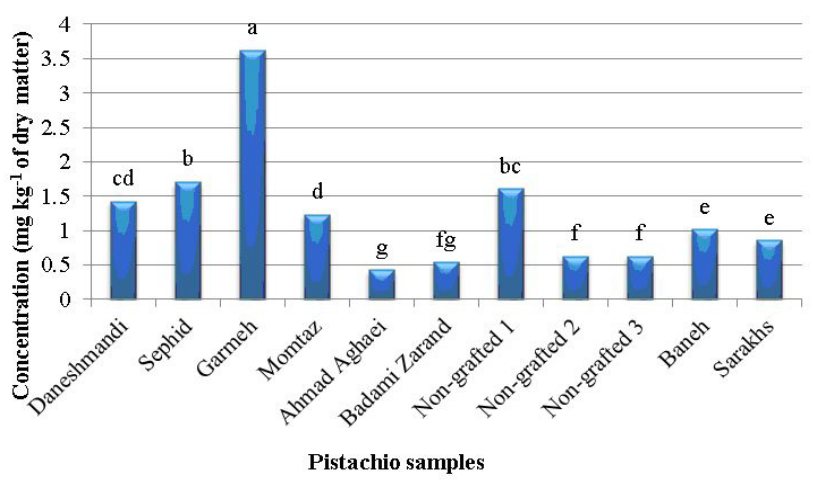

Fig. 5. The nickel concentration of eleven Iranian pistachio samples. (Each column with different letters is significantly different $(\mathrm{P}<0.05)$ 
The nickel level of pistachio has been reported as 0.36 to $13.8 \mathrm{mg} \mathrm{kg}^{-1}$ (Cabrera et al., 2003; Soylak et al., 2006).

The nickel values obtained in the current study were greater than those reported by Cabrera et al. (2003), while lower than those reported by Soylak et al. (2006). The variation may the result of other factors such as; the different pistachio samples, production place and method used in the experiments. Soylak et al. (2006) reported that the level of nickel as $17.41 \mathrm{mg} \mathrm{kg}^{-1}$ for almond and $25.80 \mathrm{mg}$ $\mathrm{kg}^{-1}$ for walnut. The level of nickel in the studied pistachio samples was lower than other nuts.

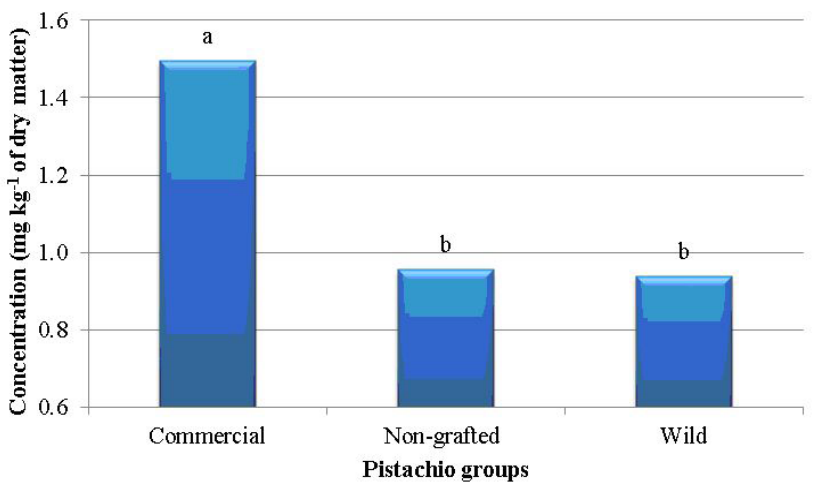

Fig. 6. The nickel concentration of three Iranian pistachio groups. (Each column with different letters is significantly different $(\mathrm{P}<0.05)$

Nickel $(\mathrm{Ni})$ is a trace element; its physiological role in plants is similar to cobalt. Its role in human body is not as clear, but it may be beneficial as an activator of some enzyme systems in small quantities (Saracoglu et al., 2009). Foodstuffs naturally contain small amounts of nickel. Several kinds of vegetables, fruits and meats are fine for consumption in regard to nickel content. The uptake of too large quantities of nickel can cause adverse effects such as; lung cancer and nickel allergy (Onianwa et al., 2000; Parveen et al., 2003).

Based on WHO (WHO, 1994), the content of nickel recommend for daily intake is 100 and $300 \mu \mathrm{g}$. We found that the average level of nickel of examined pistachio samples was $1.25 \mathrm{mg} \mathrm{kg}^{-1}$ of dry matter. Based on our results, pistachio is regarded as excellent nickel source for humans, but the excessive consumption may be result in harmful effects.

\section{Copper}

There were significant differences in the copper content of pistachio samples and the values ranged from 3.20 to 12.33 ( $\mathrm{mg} \mathrm{kg}^{-1}$ of dry matter). Among the studied samples, 'Baneh' had the highest amount of copper and 'Nongrafted 2' had the lowest copper content (Fig. 7). Statistically significant differences in copper content were found among groups of wild (10.89 $\mathrm{mg} \mathrm{kg}^{-1}$ of dry matter), com- mercial ( $8.18 \mathrm{mg} \mathrm{kg}^{-1}$ of dry matter) and non-grafted (5.59 $\mathrm{mg} \mathrm{kg}^{-1}$ of dry matter) (Fig. 8).

Cabrera et al. (2003) stated the content of copper was found as $9.20 \mathrm{mg} \mathrm{kg}^{-1}$ in pistachio in Spain. Soylak et al. (2006) reported that the concentration of copper was $24.90 \mathrm{mg} \mathrm{kg}^{-1}$ in pistachio in Turkey. Our results were lower than values observed by Soylak et al. (2006), while our results were in agreement with values reported by Cabrera et al. (2003). Sattar et al. (1989) showed that the level of copper was $6.20 \mathrm{mg} \mathrm{kg}^{-1}$ for almond and $7.74 \mathrm{mg} \mathrm{kg}^{-1}$ for walnut. The copper levels of almond and walnut samples from Spain have been reported as 11.1 and $22 \mathrm{mg} \mathrm{kg}^{-1}$, respectively (Cabrera et al., 2003). Edible nuts are regarded as good source of copper. Cashew nuts provide the most copper with $2.2 \mathrm{mg}$ (111\% RDA) per 100 gram serving, Other nuts high in copper include; hazelnuts (88\% RDA), brazil nuts (87\% RDA), walnuts (79\% RDA), pistachios (66\% RDA), pine nuts (66\% RDA), peanuts (65\% RDA), pecans (60\% RDA), and almonds (59\% RDA) (USDA, 2009).

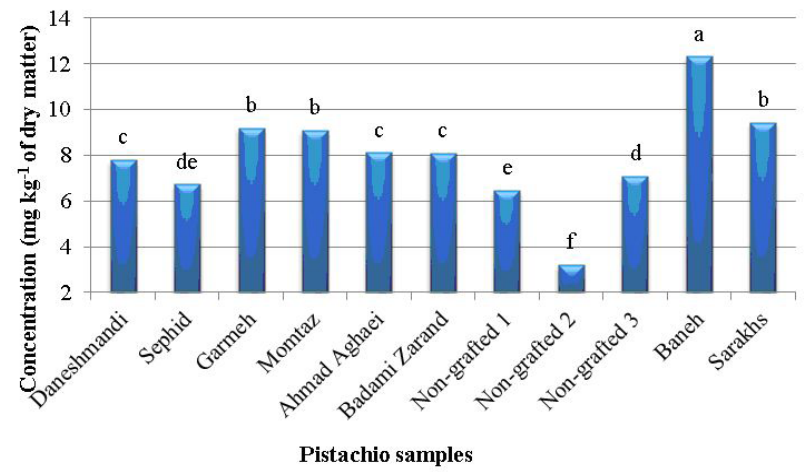

Fig. 7. The copper concentration of eleven Iranian pistachio samples. (Each column with different letters is significantly different $(\mathrm{P}<0.05)$

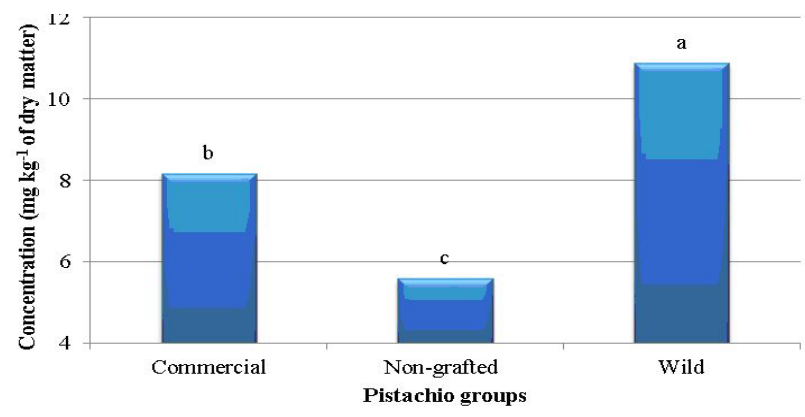

Fig. 8. The copper concentration of three Iranian pistachio groups. (Each column with different letters is significantly different $(\mathrm{P}<0.05)$

Copper $(\mathrm{Cu})$ is a trace element that plays an essential role in our life and health. It is known to be vital for many biological systems such as; enzymes function (super oxide dismutase), skin and hair pigmentation, helps in the iron 
442

intake, maintenance of connective tissue and many other functions (Saracoglu et al., 2009). Although, humans can handle proportionally large concentrations of copper, exposure too much copper can cause eminent health problems such as; hepatic and kidney damage, methanoglobinemia and hemolytic anemia (Banerjee et al., 2010).

The daily quantity of ingested copper foods has been estimated between 1 and $3 \mathrm{mg} \mathrm{day}^{-1}$ (WHO, 1994). The mean concentration of copper of pistachio samples was $7.96 \mathrm{mg} \mathrm{kg}^{-1}$ of dry matter. The data of this study also confirmed that the pistachio is a rich source of copper and approximately $250 \mathrm{~g}$ pistachio serves the recommended daily intake for an adult.

\section{Strontium}

The highest and the lowest strontium level were detected in 'Daneshmandi' and 'Non-grafted 2', respectively (Fig. 9). The results also showed that there was a significant difference between the commercial group and the other groups (wild and non-grafted). The strontium level of the non-grafted, wild and commercial groups comprised $11.21,11.52$ and $16.73 \mathrm{mg} \mathrm{kg}^{-1}$ of dry matter, respectively (Fig. 10).

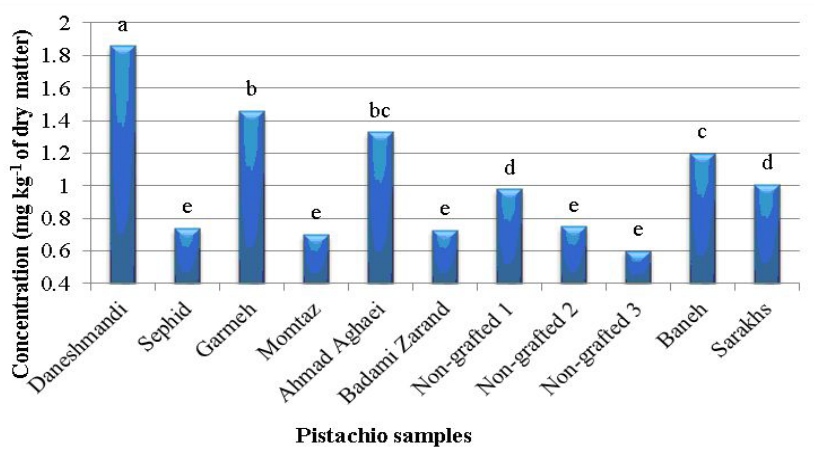

Fig. 9. The strontium concentration of eleven Iranian pistachio samples. (Each column with different letters is significantly different $(\mathrm{P}<0.05)$

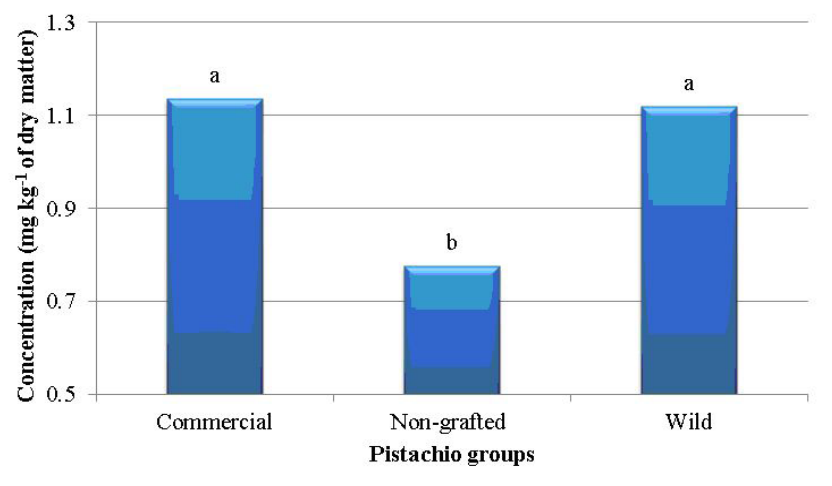

Fig. 10. The strontium concentration of three Iranian pistachio groups. (Each column with different letters is significantly different $(\mathrm{P}<0.05)$
The strontium level of pistachio samples have not been studied in detail yet. Foods containing strontium ranged from very low (e.g. in corn $(0.4 \mathrm{ppm})$ and orange $(0.5$ ppm) to high (e.g. in cabbage (45 ppm), onions (50 ppm) and lettuce (74 ppm). Foodstuffs that contain significantly high concentrations of strontium are spices, grains, leafy vegetables and dairy products.

Strontium $(\mathrm{Sr})$ is a trace mineral in the diet. Strontium bears a chemical resemblance to calcium and can displace it at times. Strontium improves the cellular makeup of bones and teeth, promotes bone development and density. It has a role in osteoblasts and osteoclasts. The uptake of high strontium concentrations is generally not known to be a great danger to human health. However, for children exceeded strontium uptake may be a health risk, because it can cause problems with bone growth and disruption of bone development. When the uptake is very high it may cause anaemia and oxygen shortages, and at extremely high concentrations it is even known to cause cancer as a result of damage to the genetic materials in cells (ATSDR, 2004). However, this effect can only occur when strontium uptake is in the thousands of ppm range.

It is estimated that the average person consumes 1 to 5 $\mathrm{mg}$ of strontium per day in food and water. The mean level of strontium of pistachio samples was $14.27 \mathrm{mg} \mathrm{kg}^{-1}$ of dry matter. According to our study, pistachio is regarded as an excellent strontium source for humans because eating 100-200 g pistachio a day covers the recommended daily intake.

\section{Conclusion}

Statistically significant differences were observed between pistachio of samples and groups investigated in all measured heavy metals except the arsenic, cadmium and cobalt. The contents of arsenic, cadmium and cobalt not reported, because their amounts were lower than the detection limit of the applied measuring method (ICP). Since all eleven pistachio samples used in this research were grown in the same location using similar agronomic practices, the differences in examined heavy metal content indicates that cultivar was the main factor determining the concentration of heavy metals in pistachio. The present study also showed that the pistachio contains high contents of strontium followed by copper, aluminium, nickel and chromium. In addition, the results provide important information on the nutritional values of pistachio samples which can be useful for selection of superior desirable pistachio genotypes for bringing to commercial cultivation. However, further investigations need to study other cultivars in Iran and explore their nutritional factors.

\section{Acknowledgements}

The authors would like to acknowledge from Department of Horticultural Science of Ferdowsi University of 
Mashhad for its kind cooperation and their assistance in different aspects of this study.

\section{References}

Ademoroti MCA (1986). Levels of heavy metals on bark and fruit trees in Benin city, Nigeria. Environ Pollut Series B 11:241-253.

ATSDR (2004). Agency for toxic substances and disease registry. Toxicological Profile for Strontium, $445 \mathrm{pp}$.

Banerjee D, Kuila P, Ganguly A, Ray L (2010). Market basket survey for chromium, copper, lead and cadmium in some vegetables from different shopping malls in Kokata, India. Electr J. Environ Agric Food Chem 9(7):1190-1195.

Biego GH, Joyeux M, Hartemann P, Debry G (1998). Daily intake of essential minerals andmetallic micropollutants fromfoods in France. Sci Total Environ 217:27-36.

Bordajandi LR, Gomez G, Abad E, Rivera J, Del Mar Fernandez-Baston M, Blasco J, Gonzalez MJ (2004). Survey of persistent organochlorine contaminants ( $\mathrm{PCBs}, \mathrm{PCDD} / \mathrm{Fs}$, and $\mathrm{PAHs})$, heavy metals $(\mathrm{Cu}, \mathrm{Cd}, \mathrm{Zn}, \mathrm{Pb}$, and $\mathrm{Hg})$, and arsenic in food samples from Huelva Spain: levels and health implications. J. Agric Food Chem 52:992-1001.

Cabrera C, Lioris F, Gimenez R, Olalla M, Lopez MC (2003). Mineral content in legumes and nuts: contribution to the Spanish, dietary intake. Sci Total Environ 308:1-14.

Celik U, Oehlenschlager J (2007). High contents of cadmium, lead, zinc and copper in popular fishery products sold in Turkish supermarkets. Food Control 18:258-261.

Cobo JM, Aguilar MV, Martinez MC (1995). Effect of chronic $\mathrm{Cr}+3$ administration and its interaction with dietary arsenic As+3 on glucose tolerance in Wistar rats. Nutr Res 15(4):555-564.

D'Mello JPF (2003). Food safety: contaminants and toxins. CABI. Publishing, Wallingford, Oxon, UK, Cambridge, MA, p. 480.

Davarynejad GH, Vatandoost S, Soltész M, Nyéki J, Szabó Z, Nagy PT, 2010. Hazardous element content and consumption risk of 9 apricot cultivars. Int J Horti Sci 16(4):61-65.

FAO (2008). Food and Agriculture Organization. (http:// www.fao.org)

Gorinstein S, Martýn-Bellosob O, Parkc YS, Haruenkitd R, Milanc ^ýz AL, Caspi A, Libmanf I, Trakhtenbergf S (2001). Comparison of some biochemical characteristics of different citrus fruits. Food Chem 74:309-315.

Jalbani N, Kazi TG, Jamali MK, Arain MB, Afrid HI, Sheerazi ST, Ansari R (2007). Application of fractional factorial design and doehlert matrix in the optimization of experimental variables associated with the ultrasonic-assisted acid digestion of chocolate samples for aluminum determination by atomic absorption spectrometry. J AOAC Int 90:16821688.

Jirapinyo P, Pringsulaka P, Kritalugsana S, Chatranon W, Cha- valittamrong B (1985). Trace elements in Thai breast milk and infant formulas. J Trop Pediatr 31:157-159.

Kucukoner E, Yurt B (2003). Some chemical characteristics of Pistachio vera varieties produced in Turkey. Eur Food Res Technol 217(4):308-310.

MSZ-08-1783-15 (1985). Nagyteljesítményű műszersorok alkalmazása a növényvizsgálatokban, Növényi anyagok fémtartalmának mennyiségi meghatározása ICP módszerrel, Hungarian Standards Institution, Ministry of Agriculture, Budapest (in Hungarian).

Munoz-Olivas R, Camara C (2001). Speciation related to human health, p. 331-353. In: Ebdon L, Pitts L, Cornelis R, Crews H, Donard OFX, Quevauviller P (Eds.). Trace element speciation for environment, food and health. Royal Soci Chem.

Narin I, Tuzen M, Soylak M (2004). Aluminium determination in environmental samples by graphite furnace atomic absorption spectrometry after solid phase extraction on amberlite XAD-1180/pyrocatechol violet chelating resin. Talanta 63:411-418.

Offenbacher EG, Pi-Sunyer FX (1988). Chromium in human nutrition. Ann Rev Nutr 8:543-63.

Onianwa PC, Lawal JA, Ogunkeye AA, Orejimi BM (2000). Cadmium and nickel composition of nigerian foods. J. Food Comp Anal 13:961-969.

Parveen Z, Khuhro MI, Rafiq N (2003). Market basket survey for lead, cadmium, copper, chromium, nickel, and zinc in fruits and vegetables. Bull Environ Contam Toxicol 71:1260-1264.

Pinochet H, De Gregori I, Lobos MG, Fuentes E (1999). Selenium and copper in vegetables and fruits grown on long term impacted soils from Valparaiso region, Chile. Bull Environ Contam Toxicol 63:327-334.

Rossini OS, Valde's B (2003). Metal concentrations in Seville orange (Citrus aurantium) fruits from Seville (Spain) and Palermo (Italy). Ann Bot Fennici 40:339-344.

Santos EE, Lauria DC, Porto da Silveiro CL (2004). Assessment of daily of trace elements due to consumption of foodstuffs by adult inhabitants of Rio de Janeiro city. Sci Total Environ 327:69-79.

Saracoglu S, Tuzen M, Soylak M (2009). Evaluation of trace element contents of dried apricot samples from Turkey. J Hazard Mater 167:647-652.

Sattar A, Wahid M, Durrani SK (1989). Concentration of selected heavy metals in spices, dry fruits and plant nuts. Plant Foods Hum Nutr 39:279-286.

Selema MD, Farago ME (1996). Tarce element concentrations in the fruit peels and trunks of Musa paradisiaca. Phytochem 42(6):1523-1525.

Shokrollahi A, Ghaedi M, Niband MS, Rajabi HR (2008). Selective and sensitive spectrophotometric method for determination of sub-micro-molar amounts of aluminium ion. J Hazard Mater 151:642-648. 
444

Soylak M, Colak H, Turkoglu O, Dogan M (2006). Trace metal content of snacks and appetizers consumed in Turkey. Bull Environ Contam Toxicol 76:436-441.

Tsantili E, Takidelli C, Christopoulosa MV, Lambrineab E, Rouskasc D, Roussosa PA (2010). Physical, compositional and sensory differences in nuts among pistachio (Pistachia vera L.) varieties. Sci Hort 125:562-568.

USDA (2009). National Nutrient Database for Standard Reference. (http://www.ars.usda.gov)

Ward NI, Savage JM (1994). Metal dispersion and transportational activities using food crops as biomonitors. Sci Total Environ 146/147:309-319.
WHO (1989). Evaluation of certain food additives and contaminants. Thirty Third Report of the Joint FAO/WHO Expert Committee on Food Additives. WHO Technical Report Series (Geneva) 776:26-27.

WHO (1994). Quality directive of potable water, $2^{\text {th }} \mathrm{Ed}$. WHO, p. 197.

Williams JR, Pillaya AE, El-Mardi MO (2005). Levels of selected metals in the Fard cultivar (date palm). J Arid Environ 60:211-225.

Zahoor A, Zahoor M (2003). Elemental distribution in summer fruits of Pakistan. Nutr Food Sci 33:203-207. 